\title{
DIET AND DEATH IN ACUTE UREMIA ${ }^{1}$
}

\author{
By T. ADDIS AND W. LEW \\ (From the Department of Medicine, Stanford University Medical School, San Francisco)
}

(Received for publication June 19, 1939)

In 1930 (1) a new way to produce a reversible acute uremia was described. The vena cava is tied above the entrance to the renal veins. In the rat this induces such an extreme congestion of the kidneys that the secretion of urine stops. The venous blood from the kidneys is obliged to run down the vena cava to the pelvis and find its way back to the heart through veins in the abdominal wall. The enlargement of these veins can be followed from day to day since they are visible through the peritoneum when the abdomen is opened. As this compensatory venous return develops, the congestion of the kidney decreases until on the second day after operation the secretion of a small amount of dilute urine begins. It contains a high concentration of protein and many renal failure casts. But the rate of excretion of urea is still deficient so that it is not until the third day that the blood urea concentration, now at very high levels - frequently more than $400 \mathrm{mgm}$. per $100 \mathrm{cc}$.- -begins to decrease. Thereafter the rates of protein, cast, and cell excretion diminish until by the seventh day after operation there is no longer any anatomical or functional evidence of a renal lesion. In all cases the rats with tied vena cavas look sick, take very little food or water, and frequently have a tremor of the entire body, exaggerated on effort. Some of them die at the height of the toxic state.

There are advantages in working with a form of uremia relatively simple in its pathogenesis and reversible by natural means, but experience has shown that valid conclusions with respect to the effect of any experimental factor can be drawn only if there is rigid uniformity with respect to the operative technique, the sex, age and general condition of the rats that are used. The operation itself is done in less than a minute. The abdomen is opened by cutting with scissors along the right costal margin. The right kidney is pulled downwards with iris forceps and, with a curved

1 This work was aided by a grant from the Rockefeller Foundation. needle, a thread is passed round the vena cava and tied. One stitch is needed for the muscles and the skin is closed with clips. In the experiments reported here only females were used. The mortality increases with age. In this work the age of the rats was 125 days. The animals used were of the Slonaker strain from which the Wistar Institute colony was derived. They had been reared under quite constant conditions on the same diet. They were not at all disturbed by handling. This may be an important variable, for all of a small series of rather wild frightened rats operated on in another laboratory died almost at once with signs of venous congestion of the lower limbs.

Death in uremia constantly follows cessation or any continued extreme decrease in the secretion of urine, and so the cause is presumably the retention of some urinary constituent. But, since injections of such substances as urea or creatinine are ineffective, it is often supposed that the causative agent may be some as yet unidentified urinary constituent, probably some nitrogen-containing derivative of protein metabolism. If this hypothesis is correct, change in the rate of protein metabolism induced by variation of the amount of protein consumed as food, by altering the concentration of the hypothetical toxic substance, should induce corresponding differences in the number of animals dying from uremia after the operation.

In constructing the diets used in these experiments, it was thought that derivatives of protein metabolism associated with the proteins in certain foods might be important. Thus casein is a relatively pure protein whereas, when meat is taken, there is with the protein a not inconsiderable quantity of nucleic acid and its derivatives along with creatin and many known and unknown nitrogen-containing substances that are not proteins. So we ground up fresh meat, liver and kidney and dried them quickly in a current of warm air. These air-dry foods were made up in 70 per cent 
concentration, with a constant concentration of lard, dry alfalfa, sardine oil and 9 per cent of dry yeast. A similar diet containing 70 per cent of an air-dry commercial casein was made. In the 16 per cent casein diet the difference between 16 and 70 per cent was made up with cornstarch, and the low protein diet contained 70 per cent cornstarch and no protein except that contained in the alfalfa and yeast. The mixed protein diet had 10 per cent of casein and 6 per cent of its protein in cereals but contained no yeast. For a week before the vena cava was tied these diets were given ad libitum, the quantities consumed were measured, and, after the operation, the foods were still given and the measurements continued. Control observations were made on the effect of these diets on the weight of the kidneys and on the blood urea concentration during the week before the operation. Under all conditions there was a zero mortality from an operation similar to that we have described with the exception that the ligature round the vena cava was not tied. All the data necessary for our present purpose are summarized in Table I.

TABLE I

Mortality within 48 hours of ligation of the vena cava

\begin{tabular}{|c|c|c|c|c|c|c|c|c|}
\hline \multirow{2}{*}{ Diet } & \multirow{2}{*}{$\begin{array}{l}\text { Num- } \\
\text { ber of } \\
\text { rats }\end{array}$} & \multirow{2}{*}{$\begin{array}{l}\text { Mor- } \\
\text { tal- } \\
\text { ity }\end{array}$} & \multicolumn{2}{|c|}{$\begin{array}{c}\text { Protein } \\
\text { consumption }\end{array}$} & \multicolumn{2}{|c|}{$\frac{\text { Kidney weight }}{\text { Heart weight }}$} & \multicolumn{2}{|c|}{ Blood urea } \\
\hline & & & $\begin{array}{l}\text { Before } \\
\text { opera- } \\
\text { tion }\end{array}$ & $\begin{array}{c}\text { After } \\
\text { opera- } \\
\text { tion }\end{array}$ & $\begin{array}{c}\text { Before } \\
\text { opera- } \\
\text { tion }\end{array}$ & $\begin{array}{l}\text { After } \\
\text { oper- } \\
\text { ation }\end{array}$ & $\begin{array}{l}\text { Bo- } \\
\text { fore } \\
\text { oper- } \\
\text { ation }\end{array}$ & $\begin{array}{l}\text { After } \\
\text { oper- } \\
\text { ation }\end{array}$ \\
\hline & & $\begin{array}{l}\text { per } \\
\text { cent }\end{array}$ & $\begin{array}{l}\text { grams } \\
\text { per rat } \\
\text { per day }\end{array}$ & $\begin{array}{c}\text { grams } \\
\text { per rat } \\
\text { per day }\end{array}$ & & & $\begin{array}{l}\text { mom. } \\
\text { per } \\
100\end{array}$ & $\begin{array}{c}\text { mom. } \\
\text { per } \\
100\end{array}$ \\
\hline $\begin{array}{l}\text { Low protein........ } \\
\text { Mixed protein..... } \\
70 \text { per cent oasein.. } \\
16 \text { per cent eacein.. } \\
70 \text { per ceat liver... } \\
70 \text { per cent hidney. } \\
70 \text { per cent beef... }\end{array}$ & $\begin{array}{l}44 \\
43 \\
54 \\
44 \\
50 \\
46 \\
55\end{array}$ & $\begin{array}{r}0 \\
0 \\
6 \\
7 \\
8 \\
9 \\
16\end{array}$ & $\begin{array}{l}0.1 \\
2.0 \\
3.9 \\
1.2 \\
3.1 \\
3.3 \\
3.7\end{array}$ & $\begin{array}{l}0.0 \\
0.2 \\
0.2 \\
0.1 \\
0.1 \\
0.2 \\
0.3\end{array}$ & $\begin{array}{l}1.87 \\
1.90 \\
2.11 \\
2.03 \\
2.13 \\
2.14 \\
2.23\end{array}$ & $\begin{array}{l}2.50 \\
2.70 \\
2.88 \\
2.70 \\
3.07 \\
2.98 \\
2.83\end{array}$ & $\begin{array}{l}22 \\
34 \\
58 \\
32 \\
38 \\
53 \\
53\end{array}$ & $\begin{array}{l}210 \\
326 \\
455 \\
310 \\
373 \\
455 \\
360\end{array}$ \\
\hline
\end{tabular}

The data in Table I are arranged in accordance with the percentage mortality within the first 48 hours after the vena cava was tied. The blood urea concentrations given in the last column are derived only from those animals that survived 48 hours and the concentrations may well have been higher in those that died. Even so the absence of any definite relation between blood urea level and mortality is surprising. The ratio between the weight of the kidney and the heart has been taken as a convenient measure of the changes in kidney weight since we have found that change in the quantity or kind of protein taken as food leaves the heart weight unaltered (2). It was anticipated that the degree of increase in the weight of the kidney arising from the venous congestion might well vary with the mortality but it is apparent from Table I that there is no definite correlation with this anatomical factor in spite of the fact that, in the control-unoperated animals, the increase in the weight of the kidney induced by increase in protein consumption happens to follow the mortality results. The principal result obtained is the demonstration that there is no relation between the death rate and the amount of protein consumed before or after the uremia was induced. This is sufficiently shown by the results of a 16 and 70 per cent casein diet.

The 16 per cent mortality rate when beef was fed was so much higher than on the other diets that we were led to suspect that muscle fibers might contain some non-protein extractive, possibly an amine, that was increasing the concentration derived from endogenous sources to lethal levels. We therefore turned our attention to meat extracts. The most available material was a commercial product prepared by the concentration of a water extract of fresh meat heated to a temperature of $80^{\circ} \mathrm{C}^{2}$ When $1 \mathrm{cc}$. of this extract was given by stomach tube at the time of operation or when the 10-times-diluted extract was given as food before operation, there was a 52 per cent mortality between 24 and 48 hours, i.e., during the period when the nitrogen retention was approaching its maximum.

In the older literature there are reports of the isolation of toxic amines from meat, so our first step was to extract the meat extract with alcohol in which all the " meat bases" are soluble. We found that alcohol dissolved 61 per cent of the total solid matter in the meat extract. The alcohol was evaporated and the residue dissolved in water so that it contained the same concentration of solids as the original meat extract, and it was given to the rats in the same dose and under the same conditions as the original extract. None of

\footnotetext{
2 We are indebted to the Valentine Meat Juice Company for a supply of Valentine's Meat Juice without any added. glycerine.
} 
these rats died. On the other hand, the alcoholinsoluble fraction, when similarly made up and administered, killed more than half the animals. This experience made us suspect that the toxicity was due not to any organic substance but to inorganic salts. The ash of the toxic alcohol-insoluble material we administered was 18 per cent while the non-toxic alcohol-soluble fraction was only 6 per cent. Since the ash of muscle consists almost wholly of potassium salts, we made up a solution of $\mathrm{KH}_{2} \mathrm{PO}_{4}$ and $\mathrm{KCL}$ which had about the same ash content as the toxic alcohol-insoluble fraction. Given in the same doses it had the same effect and was followed by the death of more than half the rats whose vena cavas were tied.

We therefore believe that the high mortality of our uremic rats given the 70 per cent beef diet was due to potassium. This supposition is supported by the work of Bergman and Drury which appears in this number of the Journal. Independently and using a different method they reach the same conclusion.

Though we have failed to find any particular substance responsible for death in the rats kept on other diets, these experiments should be recorded if only because they are an indication that large doses of potassium salts may be dangerous if they are given as diuretics to uremic patients, particularly in the uremia that follows anuria or extreme oliguria.

\section{CONCLUSIONS}

1. Before and after the vena cava was ligatured above the entrance to the renal veins (an operation that produces a transient anuria and a great increase in blood urea concentration), groups of rats, each group consisting of more than 40 animals, were given diets designed to induce a wide variation in protein consumption and protein catabolism.

2. None of the animals died when they were given diets on which the protein consumption was low or which led to a moderate consumption of the proteins of milk and cereals.

3. On diets containing 9 per cent dry yeast, whose main protein constituent was casein, variation in the amounts of casein consumed had no effect on the mortality rate.

4. On diets in which large amounts of proteins derived from dried liver, kidney and beef were consumed, the mortality rates were 8,9 , and 16 per cent respectively.

5. A water-soluble extract of meat induced a 52 per cent mortality but it was found that the alcohol-soluble fraction of this extract gave a zero mortality, while the alcohol-insoluble fraction killed more than half the animals.

6. A solution of potassium acid phosphate and potassium chloride, given in approximately the same dose, had the same effect on mortality rate as the alcohol-insoluble fraction of the water extract of meat.

7. The conclusion is drawn that potassium was responsible for the high mortality when meat extract or the alcohol-insoluble fraction of meat extract was administered and that it is probable that potassium was also a factor in the relatively high death rate following the consumption of large amounts of beef.

\section{BIBLIOGRAPHY}

1. Addis, T., and Raulston, B. O., A reversible form of experimental uremia. Tr. A. Am. Physicians, 1930, 45, 318.

2. Walter, F., and Addis, T., Organ work and organ weight. J. Exper. Med., 1939, 69, 467. 